\title{
A case study on solar, wind and hydro energy resource potential of Prizren region in Kosovo
}

\author{
Shiplu Sarker ${ }^{1, *}$, Goneta Pecani $^{1}$, Dejon Vula ${ }^{1}$ and Alemayehu Gebremedhin ${ }^{1}$ \\ ${ }^{1}$ Norwegian University of Science and Technology, Department of Manufacturing and Civil Engineering, 2815 Gjøvik, Norway
}

\begin{abstract}
Prizren is a city located in the south part of Kosovo with approximately 90,000 inhabitants and land area of $640 \mathrm{~km}^{2}$. The region is covered with distinct geographical features, that favor penetration and deployment of various forms of renewable energy. Particularly, solar, wind and hydro energy potential are considered to be the most available options here. In this study, the potential of these renewable energy sources and their viability for energy production are evaluated using a computational modeling tool. The potential investment opportunities are analyzed based on a 50-year life time project. The results suggest that integrating renewable energy to the existing energy system will enable Prizren region and partly the entire Kosovo for coping with load fluctuations in energy demand. Also, it is expected that the added renewable energy in the existing energy mix will, in a broad perspective, lead to meet the European Union's target of accelerated renewable energy penetration by the year 2030, and in turn to reduce the greenhouse gas emission to the environment.
\end{abstract}

\section{Introduction}

Kosovo's current energy system gets more than 95\% [1] of its energy need from the two main coal power plants "Kosova A" and "Kosova B" [2-3], built in 1962 and 1983 respectively, and have been running with poor operating conditions since inception. Consequently, a very high $\mathrm{CO}_{2}$ emission factor of $1290 \mathrm{kgCO}_{2} / \mathrm{kWh}$ for Kosovo has been an evident outcome [4]. The latest EU directives [5] call for a $30 \%$ overall renewable energy penetration by 2030 for its member states, and Kosovo's ambitions to be part of EU mean that it will also need to fulfill this directive. Achieving the renewable energy penetration target is both an opportunity and a challenge for Kosovo, considering that the coal power plants which currently supply the majority of the energy are planned to be decommissioned or getting a major makeover in the coming years. This means that there will be an unmet need for the load.

Although ubiquitously available, exploring renewable energy resources are both technology and economic challenge, and looking at the overall renewable resources in Kosovo, a mixed picture of both sufficient and insufficient potentials particularly for the three major renewable energy sources such as solar, wind and hydro can be recognized. On an average, solar potential up to $1700 \mathrm{kwh} / \mathrm{m}^{2}$ is available, while average wind speed was found to be insufficient with only category IV [6] potential, which is only able to produce power with the use of modern turbines. Mean hydro power resources are also found to be largely unpredictable and insufficient in most locations.
While the average renewable energy resource potential throughout Kosovo is marginal, Prizren region, a site located in the southmost of Kosovo, has the highest concentration of simultaneous solar, wind and hydropower. According to European Commission photovoltaic geographical information system [7], Prizren by far has the best solar potential in the country, although to accurately predict this potential using computational modeling is complex and influenced by its geographical characteristics of non-uniform sunshine and shadows in the mountainous terrains. In contrast, a rather accurate historical wind data of the region can be directly accessed from the satellite [6] which further can be evaluated for wind energy potential quite easily using computational modeling analysis. A location between Brod and Zilipotok villages $\left(41.986459^{\circ} \mathrm{N} ; 20.681316^{\circ} \mathrm{E}\right)$ offers the highest annual wind speed of $5.24 \mathrm{~m} / \mathrm{s}$ in Prizren, which has the potential to deliver quite a substantial wind power using modern day wind turbines. At present, only $\sim 2 \mathrm{MW}$ of wind power is generated across Kosovo in contrast to the potential capacity of $\sim 100 \mathrm{MW}$ upon complete utilization of the available resources. This means that a large potential until to date is not utilized, and thereby an accelerated future R\&D effort in this direction will be required, bringing in more convenient technologies and perhaps the political attention towards technology expansion. Besides solar and wind, hydropower potential in the region was also evaluated [8] to be amongst the highest within Kosovo, characterized with high water flowrate on the river Drini i Bardhë at Dragash $\left(41.5230^{\circ} \mathrm{N} ; 20.4826^{\circ} \mathrm{E}\right)$. In a past study [8], the hydropower generation potential of 293 MW electricity from Drini river corresponding to $30 \%$ of the total

Corresponding author: shiplu.sarker@ntnu.no 
hydropower in Kosovo was mentioned. Currently, only about $45 \mathrm{MW}$ of hydropower is produced across Kosovo, although there is an immense potential in harvesting many small streams and river heads which can easily contribute to elevate the present capacity in multiple orders. A feasibility study [8] of Dragash region in Prizren consisting of two hydropower generation points: 'Zhuri I' and 'Zhuri II' was already carried out, and the results advocating the suitability of future hydropower installation was reported.

Taking into considerations the outcome of these past studies regarding different renewable energy potentials within Prizren, the present study focuses on application of the available potential in a $100 \%$ renewable energy context and then to assess its techno-economic feasibility by comparing the existing fossil fuel based system. A generalized scheme of the proposed new system in comparison to the existing energy system is depicted in Figure 1.

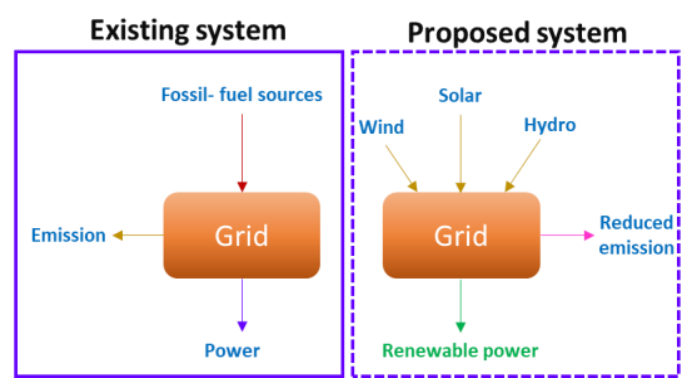

Fig. 1. Comparison between existing and proposed energy system in Prizren.

\section{Methods}

A microgrid optimization tool hybrid optimization of multiple electric renewables (HOMER Energy) developed by the NREL (National Renewable Energy Laboratory, USA) was used for techno-economic feasibility analysis of the proposed energy systems, developed based on the ascending order of net present cost (NPC) values.

\subsection{Resources}

The renewable energy resources solar, wind and hydro were considered in the present study.

The monthly solar irradiation and average temperature of Prizren city were obtained from the satellite data available from NASA. While the default wind energy data from NASA were modified based on the on-site measurements given in [6]. The hydrological data were taken from [8] as yearly averages and then normalized these with the monthly rainfall averages from [9] in order to present the monthly data in terms of average stream flow. The residual flow was calculated from the annual average flow following the procedure described by Jing L. et al. [10]. The monthly solar irradiation, clearness index and temperature averaged for over 22 years by the NASA satellite are presented in Table 1, while the wind and the stream flow data for the same duration are given in Table 2.
Table 1. Monthly clearness index, solar irradiation and atmospheric temperature of the studied site.

\begin{tabular}{|l|l|l|l|}
\hline Month & $\begin{array}{l}\text { Clearness } \\
\text { index }\end{array}$ & $\begin{array}{l}\text { Daily } \\
\text { irradiation } \\
\left.\mathbf{( k W h} / \mathbf{m}^{2} / \mathbf{d a y}\right)\end{array}$ & Temperature \\
\hline January & 0.495 & 1.93 & $-0-37$ \\
\hline February & 0.492 & 2.63 & 1.06 \\
\hline March & 0.514 & 3.82 & 4.99 \\
\hline April & 0.473 & 4.51 & 9.88 \\
\hline May & 0.520 & 5.72 & 15.44 \\
\hline June & 0.593 & 6.88 & 19.59 \\
\hline July & 0.621 & 6.98 & 22.54 \\
\hline August & 0.607 & 6.04 & 22.48 \\
\hline September & 0.561 & 4.49 & 17.70 \\
\hline October & 0.539 & 3.15 & 12.08 \\
\hline November & 0.470 & 1.96 & 5.69 \\
\hline December & 0.444 & 1.540 & 0.670 \\
\hline
\end{tabular}

Table 2. Monthly wind and water stream flow of Prizren.

\begin{tabular}{|l|l|l|}
\hline Month & $\begin{array}{l}\text { Wind speed } \\
(\mathbf{m} / \mathbf{s})\end{array}$ & $\begin{array}{l}\text { Water stream } \\
\text { flow (L/s) }\end{array}$ \\
\hline January & 5.660 & $6,179.417$ \\
\hline February & 5.930 & $7,209.320$ \\
\hline March & 5.630 & $9,269.126$ \\
\hline April & 5.360 & $16,478.450$ \\
\hline May & 4.630 & $21,627.960$ \\
\hline June & 4.580 & $11,328.709$ \\
\hline July & 4.670 & $6,179.417$ \\
\hline August & 4.800 & $4,119.612$ \\
\hline September & 4.760 & $3,089.709$ \\
\hline October & 5.230 & $7,209.320$ \\
\hline November & 5.630 & $9,269.16$ \\
\hline December & 5.990 & $4,119.612$ \\
\hline
\end{tabular}

\subsection{System components and load data}

The energy components used for simulation include photovoltaic (PV) modules, wind turbines, hydropower turbines, converter and grid.

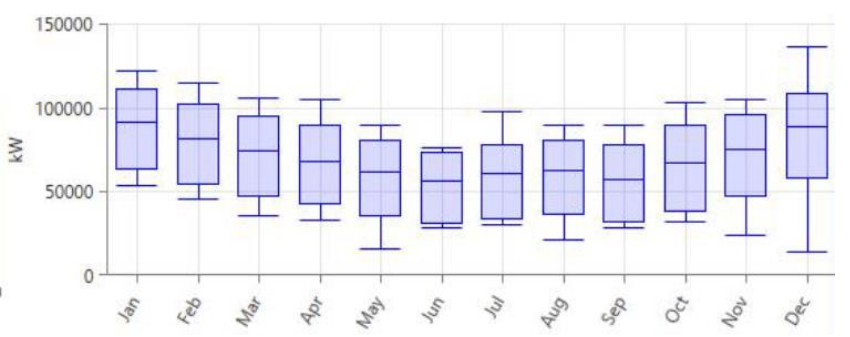

Fig. 2. Annual load data of Prizren for the year 2015.

The load data as mentioned before was input as an hourly time series file developed from adding the transformer load data provided by KEDS Energy (an electric distribution company in Kosovo) and shown in Figure 2. It can be seen that around $1,700,000 \mathrm{kWh}$ of energy was consumed during 2015 for Prizren with yearly loads peaking in the winter months.

\subsubsection{PV modules}

In order to match the selected solar panel's [11] technical specifications with the onsite data, the XML file of the 
HOMER interface was modified. The modified data was then added to the list of the PV panels available in the existing libraries. The number of solar panels for evaluation was varied from 0 (no solar panels) to 18 so the production does not exceed the site's maximum technical potential.

\subsubsection{Wind turbines}

Likewise PV panels, the chosen wind turbine's specification was also input partly as interface data and partly as a new XML file, allowing to add the turbine GE 1.7-103 to the library of the existing wind turbines in HOMER. The amount of wind turbines to be considered for the project was input from 0 (no wind turbines) to 13 (matched with the maximum technical potential of the chosen site).

\subsubsection{Hydro power plant}

The hydro power plant input parameters were mainly used from the prior economic calculations (capital cost, replacement cost, designed flow rate and project lifetime) provided in [9], while the available head was included as a combination of the heads available in the "Zhuri I" and "Zhuri II" parts of the Zhur area dam on the river Drini i Bardhë. The O\&M cost was calculated based on the procedure described by Fang Z. H. et al. [9], while the minimum flow rate was given as a ratio value shown by Jing L. et al. [10]. The efficiency of the power plant was calculated as the ratio between installed and actual capacity, while the penstock pressure loss was assumed from [12].

\subsubsection{Storage and converter}

For the storage and converter modules, the technoeconomic specifications of the Tesla Powerwall and Powerpack (utility scale) battery plus inverter modules were used [13]. The input amount of storage and converters were varied from 0 unit (no batteries and converters) to 18.000 units, to cover the power output of the solar PV generation.

\subsubsection{Grid}

The advanced grid module was used, where the purchase and sale capacity were set to a slack bus (input as $1 * 10^{\wedge} 18$ ) to not limit the purchase and sale capacities of the project, since the Kosovo power system is a strong and internationally interconnected entity. The grid's investment costs were assumed as $1.800 .000 € / \mathrm{km}$ according to Acerman M. et al. [14]. The rate definition was used according to Kosovo's Energy regulatory office as high and low rates for winter and summer months respectively, together with a fixed sellback price [15].

\subsection{NPC and emission calculation}

HOMER evaluates the NPC of a plant by determining the plant's present value minus all profits gained over expected lifetime. The annual value of the NPC is then determined from the total annual cost using default NPC equation.

For emissions calculation HOMER takes into account six pollutants $\mathrm{CO}_{2}, \mathrm{CO}$, unburned hydrocarbon (UHC), particulate matter (PM), $\mathrm{SO}_{2}$ and $\mathrm{NO}_{\mathrm{X}}$ and tabulates their annual emissions per kilogram of fuel input.

\section{Results \& Discussions}

\subsection{Optimum energy system}

From the HOMER simulation results it can be observed that the optimum configuration consists of $18,000 \mathrm{~kW}$ PV panels, 13 units of GE1700 wind turbines, $1 * 10^{\wedge} 18 \mathrm{~kW}$ of grid, $29,1033 \mathrm{~kW}$ of hydropower and $14,000 \mathrm{~kW}$ of converter, illustrated as screenshot in Figure 3.

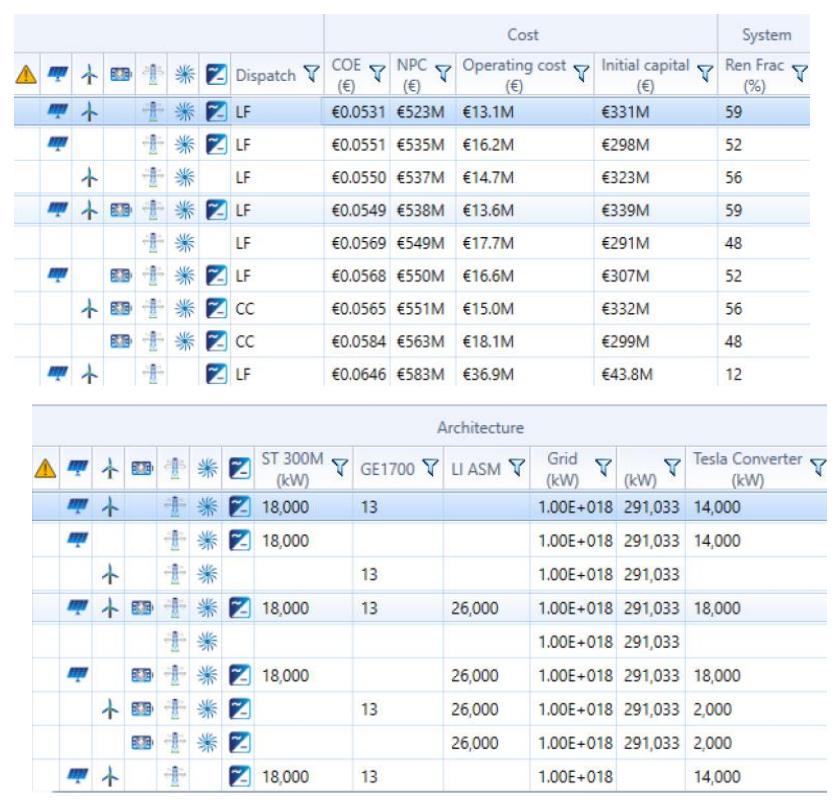

Fig. 3. Techno-economic assessment results of optimum system

For this configuration, hydropower has the highest capital cost, followed by wind turbines, PV modules, grid and converters. Even though the considerable investment cost, the hydropower and grid have no replacement cost, which enables to lower the total system NPC. In addition, since the system components are operated on renewable energy, there is no fuel cost. However, the requirement of routine maintenance results in O\&M cost, which comprises in the descending order of: grid, hydro, wind turbine, PV modules and converters. The different cost values of the optimum system components are presented in Table 3.

In terms of economic calculation, the cumulative cash flow of the optimum configuration compared to the existing configuration (operated with grid only) is found to reach at a break even in about 11 years and to payback with $8.3 \%$ discount rate in $\sim 23$ years. Extending the cash flow analysis to the full 50 years of the project's life, a remarkably higher cash flow during the first year due to the investment, and a rather high value at the year 25 due 
to the requirement of partial replacement of the components (which were considered to have a life time of 25 years in HOMER simulation) is observed. The cashflow for the rest of the years otherwise stays stable.

Table 3. Cost analysis of optimum system components

\begin{tabular}{|l|r|r|r|}
\hline Component & \multicolumn{1}{|l|}{ Capital (€) } & \multicolumn{1}{l|}{$\begin{array}{l}\text { Replacement } \\
(\boldsymbol{\epsilon})\end{array}$} & \multicolumn{1}{l}{ O\&M (€) } \\
\hline Wind turbine & $2,223,565$ & 454,595 & 325,000 \\
\hline Hydro & $19,636,959$ & 0 & $1,360,000$ \\
\hline Grid & 246,302 & 0 & $10,866,767$ \\
\hline PV & 492,605 & 100,710 & 21,600 \\
\hline Converter & 34,208 & 6,993 & 5,000 \\
\hline System & $22,633,642$ & 562,300 & $12,578,367$ \\
\hline
\end{tabular}

\subsection{Electrical output}

The electrical output of the different components is depicted by Figures 4 through 7. As observed (Fig. 4), the yearly output of the PV arrays is relatively constant peaking at summer months. While in the winter months, a few sunny days coupled with the clean atmosphere and cold climate (a good environment for solar panels) are the only periods contributing to the power production. The PV penetration of the studied site in the Prizren region is expected to cover $4 \%$ of the total renewable power with the capacity factor of $15.67 \%$.

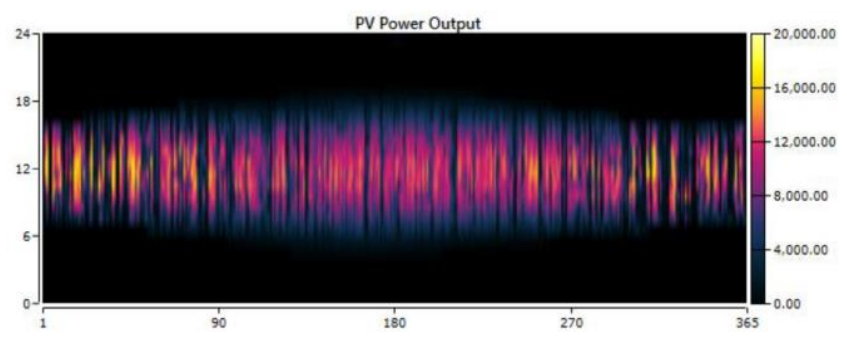

Fig. 4. Annual electrical power output from the PV arrays

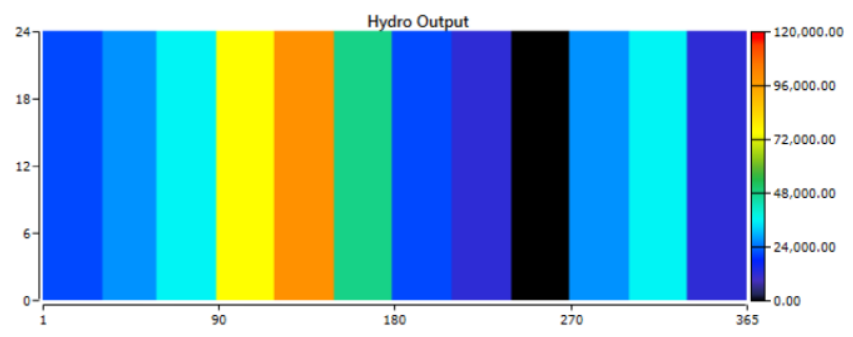

Fig. 5. Annual electrical power output from hydropower plant

The hydro power plant produces a substantial output with around $300,000,000 \mathrm{kWh} /$ year for an expected capacity factor of $\sim 13 \%$, which is however lower than those for the above two sources. This is because that the planned hydro power plant (HPP) is purposely oversized to make use of the available reservoirs, which in addition can serve as the load regulator of the entire Kosovo's energy system. For the Prizren region, the building of this HPP system would account for around 52\% hydro energy penetration.
The wind turbines generate a mean yearly output of $\sim 52,000,000 \mathrm{kWh}$ with a capacity factor of $\sim 27 \%$. Like PV power, the yearly production from the wind turbines is also pretty constant, lowering during summer and picking during winter months (Fig. 6). This pattern of annual power yield closely matches with the input load, making the obtained results interesting in real-life application. An overall wind power generation is forecast to cover $8.4 \%$ of the total demand of the proposed Prizren region.

The converter output is limited to inverting the DC power generated from the solar PV arrays and matches with the PV array output, but it doesn't function as a rectifier, since the optimum case doesn't include batteries as energy storage units. The HOMER simulation has evaluated the optimal PV peak/converter ratio to about 1.28. As this ratio depends on the local climate, the PV surface orientation and inclination, and the typical ratio at which PV power remains unaffected varies between 0.6 and 0.7 in many countries across Europe [16], the obtained ratio might result in some PV power loss. However, the optimal ratio causes to reduce the investment costs as well as allows capacity factor to escalate at $\sim 19 \%$.

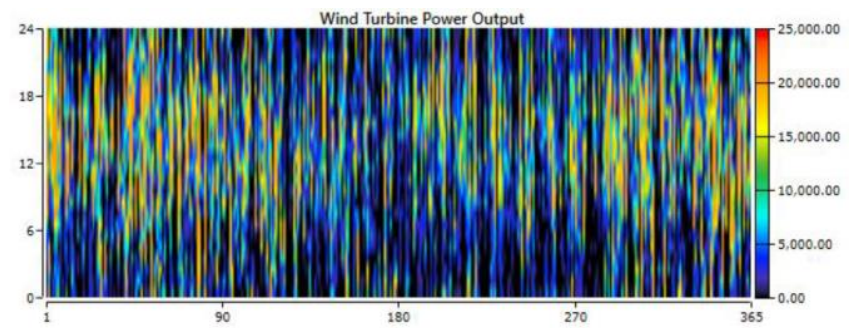

Fig. 6. Annual electrical power output from wind turbine

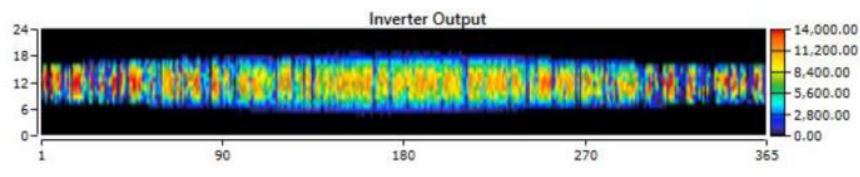

Fig. 7. Annual electrical power output from converter

\subsection{Renewable energy penetration}

As logical, the renewable energy penetration varies throughout the year with the seasonal fluctuations of the available resources. While the designed peak is rated as $100 \%$, the median renewable energy penetration is found to be around $\sim 58 \%$. From the heat map (Figure 8 ), it can be seen that the late spring and late fall months provide the highest renewable energy penetration because of the higher water flow availability in the HPP, while the lowest being in the summer months. This pattern of renewable energy yield is pretty much compatible with the input load curve, and thereby offers a reliable solution to the electricity demand within Prizren. 


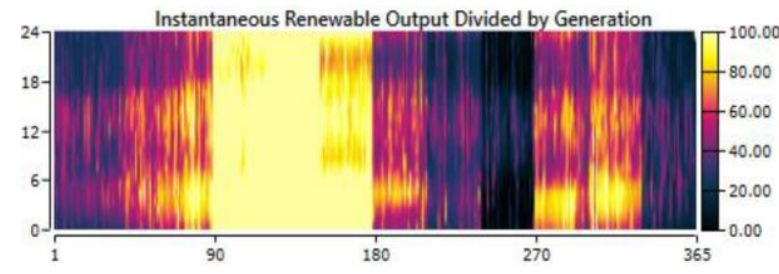

Fig. 8. Heat map for annual renewable energy penetration output

\subsection{Emission reduction}

Since the proposed energy system with high rated capacity operates solely based on renewable energy sources, replacing the existing coal power plants, which facilitate the majority of the current energy demand, an enormous amount of carbon dioxide emission saving is possible. By calculating the amount of grid energy saved, HOMER gives a corresponding yearly emissions reduction of around 287,000 ton $\mathrm{CO}_{2} / \mathrm{yr}$. The calculated emission results are presented in Table 4.

Table 4. Emission reduction quantities from the proposed system

\begin{tabular}{|l|l|l|}
\hline Quantity & Value & Units \\
\hline Carbon dioxide & $286,956,736.29$ & $\mathrm{~kg} / \mathrm{yr}$ \\
\hline Carbon monoxide & 0.00 & $\mathrm{~kg} / \mathrm{yr}$ \\
\hline Unburned hydrocarbons & 0.00 & $\mathrm{~kg} / \mathrm{yr}$ \\
\hline Particulate matter & 0.00 & $\mathrm{~kg} / \mathrm{yr}$ \\
\hline Sulfur dioxide & $609,505.01$ & $\mathrm{~kg} / \mathrm{yr}$ \\
\hline Nitrogen oxides & $298,079.09$ & $\mathrm{~kg} / \mathrm{yr}$ \\
\hline
\end{tabular}

\section{Conclusions}

The renewable energy resources around the Prizren region are widespread and characterized with high potential and concertation. Of these resources, the average yearly solar radiation was found to be between 1600 and $1700 \mathrm{kWh} / \mathrm{m}^{2}$, wind speeds to be $4-6 \mathrm{~m} / \mathrm{s}$ and the water flow through the Drini i Bardhë river (Zhur HPP) being $8-9 \mathrm{~m}^{3} / \mathrm{s}$. The electricity grid throughout the region is also quite extensive, but this has some intolerances in extra power flow in sporadic occasions.

The modeling results presented in the current work have shown that the proposed energy system, once implemented, is able to satisfy the present electricity demand of Prizren region using 100\% renewable sources and consequently to give lesser emission of GHG gases as compared to the existing fossil fuel based system. Moreover, the obtained results can pave the way for future research exploring more sites within Kosovo.

The first author of this paper expresses his sincere gratitude to the second and third authors for data processing and the production of artworks. The modeling facility provided by NTNU is also acknowledged.

\section{References}

1. World Bank, Kosovo country environmental analysis, 1-100 (2013).

2. KEK, Termocentrali Kosova A (2016) (http://kekenergy.com/kek/termocentrali-kosova-a/, accessed on 15.01.2020)

3. KEK, Termocentrali Kosova B, (2016)

4. IEA, $\mathrm{CO}_{2}$ emission statistics, (2019) (https://www.iea.org/subscribe-to-data-services/co2emissions-statistics, accessed on 15.01.2020)

5. European Commission, Proposal for a directive of the European parliament (European Commission, Brussels, 2016)

6. Vortex, Modeled wind resource data for the wind industry, (https://vortexfdc.com/, accessed on 15.01.2020)

7. EU science hub, Photovoltaic Geographical Information System (PVGIS) (https://re.jrc.ec.europa.eu/pvg_tools/en/tools.html\# $P V P$, accessed on 15.01.2020)

8. Z. Idri, I. Idri, 159-163 (2006) (Dams and Reservoirs, Societies and Environment in the $21^{\text {st }}$ Century, 2006)

9. Z. H. Fang, K. Zena, Technical report on the hydrology of the Drini river basin (2010) (accessed on 15.01.2020)

10. L. Jing, O. Stephansson, Fundamentals of Discrete Element Methods for Rock Engineering, Develop. in Geotech. Engg. 85, 317-364 (2007)

11. European Commission, Study on tariff design for distribution systems, (2015) (https://ec.europa.eu/energy/sites/ener/files/documen ts/20150313\%20Tariff\%20report\%20fina_revREFE.PDF, accessed on 15.01.2020)

12. J. K. Kaldellis, D.S. Vlachou, G. Korbakis, Solid attitude towards wind energy applications in Greece. Ener. Policy. 33, 1969-1985 (2005)

13. Tesla, Tesla power everything (https://www.tesla.com/energy, accessed on 15.01.2020)

14. M. Acerman, M. J. Dunbar, Hydro. \& Earth Sys. Scien. 8, 861-876, (2004)

15. J. Yli-Hannuksela, (The transmission line cost calculation, 2011)

16. R. S. Faranda, H. Hafezi, S. Leva, M. Mussetta, E. Ogliari, The optimum PV plant for a given solar DC/AC converter, Energies 8, 4853-4870 (2015) 